8
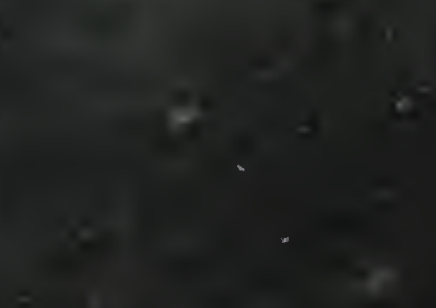


\section{Wetlands Protection Program Policies}

GOVERTMENT DOCUMENTS

COLLECTION!

NOV 61987

Univarsivy of liessachusetis
Dasository Copy

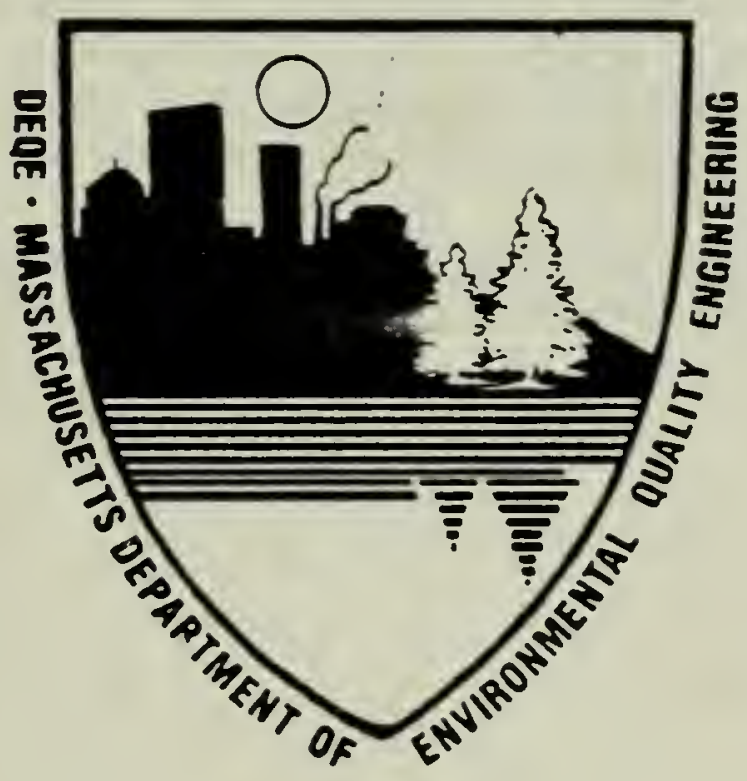

$5 \cdot 3315$

Department of Environmental Quality Engineering Division of Wetiands and Waterways Regulation One Winter Street, Boston 02108 


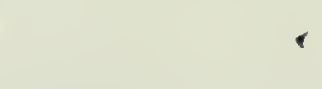




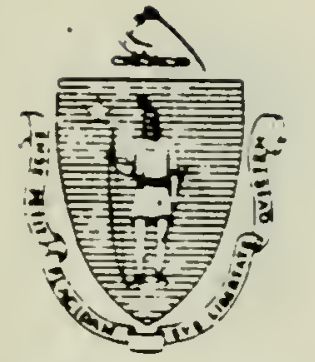

S. RUSSELL SYLVA Commissioner

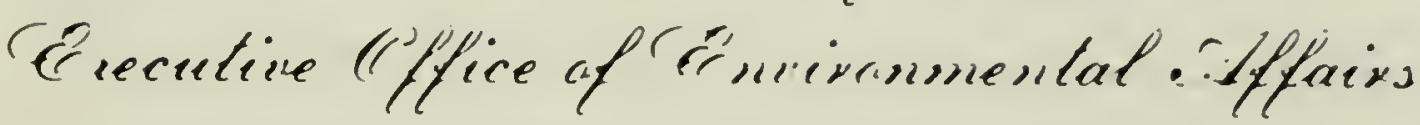

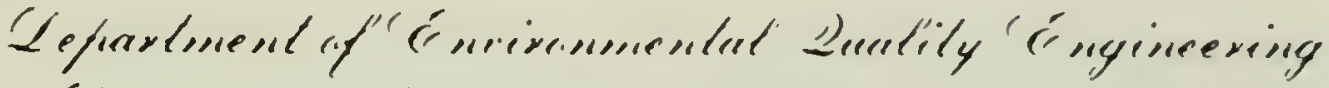

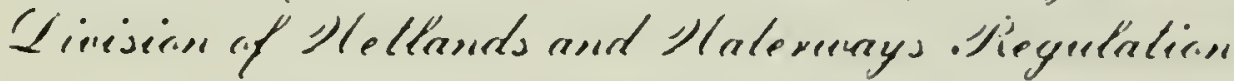

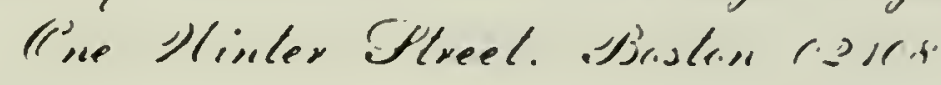

Gary Clayton, Division Director

ON THE DISTRIBUTION OF DIVISION WETLAND POLICIES

From time to time the DEQE Division of Wetlands and Waterways Regulation issues formal policies interpreting the Wetlands Protection Act (Ch. 131, S.40) and regulations (310 C.R 10.00). Unlike regulations, policies do not have the force of law. Rather, they spell out the criteria DEQE will use in making decisions. This guidance will help avoid appeals and will promote statewide consistency in wetlands decision-making. Note: Policies are numbered sequentially within each year.

The new policies will be published regularly in the Wetland Report, the Division's quarterly newsletter. 


\section{Digitized by the Internet Archive in 2013 with funding from Boston Library Consortium Member Libraries}




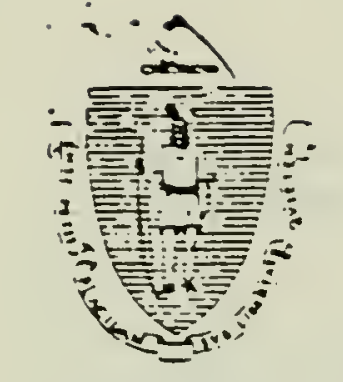

S. RUSSELL SYLVA Commissioner
The Cammanumealth of e llassachusetts

\section{$M E M O R A N D U M$}

TO: Regional Environmental Engineers

Wetlands Program Staff

Conservation Commissions

office of the General Counsel

FROM: Gary Clayton, Director

Division of Wetlands and Waterways Regulation

DATE: JUIY 11, 1986

RE: WETIAANDS PROGRAM POLICY 86-1: 310 CMR 10.03(3)

Presumptions For Subsurface Sewage Disposal Systems That Meet Title 5 or More stringent Local Board of fiealin Requirements.

The Wetlands Regulations, at 310 CMR 10.03(3), establish a presumption that a subsurface sewage disposal system. which complies with the requirements of Title 5 or more stringent local Board of Health requirements. protects the interests of the Wetlands Protection Act (the "Act"). This presumption, however, only has effect if none of the components of the syster are located within certain resource areas protected by the Act, and if the leaching facility of the system is located at least 50 feet from the boundary of those areas, or a greate: distance if required by a local Board of Healeh by-law or regulation. Conservation Comissions and the Department. however, have only limited authority to enforce more stringent local Board of Health requirements because neither has the authority to interpret ambiguous language that may be included in those by-laws or regulations or to determine whether the local Board of Health should grant a variance from the local standards. Therefore, the Department adopts the following guidelines for applying the provisions of 310 CMR 10.03(3):

(1) When reviewing a Notice of Intent, a Conservation Commission or the Department must determine whether a proposed sewage disposal system meets the fifty foot wetland set-back requirements of 10.03. Usually. Title 5 issues other.than wetlands set-backs should be left to the Board of Health uniess there is overwhelming evidence that the Board of Health has failed to properly review the case. The Title 5 requiremenss that may be considered are limited to those, such as the requirements for "perc" tests, where a system not in compliance would have the potential to impa: resource azeas identified in 10.03(3). It is highly unlikely, therefore, that a siandazd 

such as a lot-line set-back requirement should ever be considered in a wetlands review.

(2) As stated above, neither a conservation Commission. nor the Department have the authority to interpret Board of Health regulations or to decide whether a local Board of Health will issue a variance from its own regulations. Where a proposed project meets the requirements of Title 5, but may fail to meei more stringent local standards. The Conservation Commission and the Department have two recommended alternative courses of action:

a) Where it is clear that the system does not meet the local Board of Health requirements, such as when the Board of Health has already denied a request for a permit. the Conservation Commission or the Department could deny the project and require the applicant to obtain a permit from the local Board of Health prior to the issuance of an Order of conditions. Suggested wording for such a denial is:

"This project is denied because it does not meet the setback requirements of the [-Town Name] Board of Health and therefore does not have: the benefit of the presumption under $310 \mathrm{CMR}$ 10.03. A new Notice of Intent may be filed if the [Town Name] Board of Healtb issues a permit, or the project is revised to meet the [Town Name] Board of Healih requirements."

Conservation Commissions and the Department must be careful when using chis alternative. Many Boards of Health simply will not take any action before the issuance of an order of Conditions. It would not be proper. therefore, to create a situation where the applicant is placed in the impossible position of having neither approval available until the othe: is obtained.

b) If the only question about the permissibility of the proposed work is whether it will receive a local Board of Health permit, it is generally preferable for the conservarion Commission or the Department to issue an order of Conditions that will permit the work on the condition that the applicant subsequently receives a local Board of Health permit. suggested wording for such a condition is:

"No work permitred by this Order may begin unless and unz: I the applicant receives a subsurface sewage disposal permit from the ['town name'] Board of Health, and until a copy os said permit is sent to the Conservation Commission and the Department."

The Conservation Commission or the Depaztment are responsible for making the werland boundary delineaiion for the Boazd of Healch to use in its review. Generally. this delineãion will cake place when the applicant's plans have been reviewed and found accurate. or modified in accordance with the fincings os the Conservation Commission or the Department. 



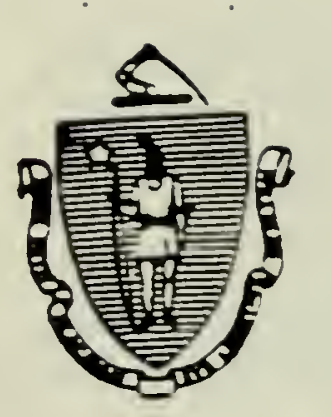

S. RUSSELL SYLVA Commisionor

WILLARD R. POPE General Counsel

The Commonuealth of Massachusetts Execulive. Office of Envivanmental Affeains Depaxtment of Encivanmental Quality Ëngineexing One Ulinter Sued, DDatan 02108 Office of. General. Gounsed, Tel. 292-5568

\section{MEMORA N D U M}

To: Regional Environmental Engineers Wetland Protection Program Staff Legal office

THROUGH: Gary Clayton, Director

FROM:

Matthew Watsky.

Assistant General Counsel

Rw

DATE: $\quad$ Noverber 26,1985

SUBJECT: Wetlands Protection Program Policy 85-5

Enforcement Orders. Appeal Language

This memorandum is to clarify the procedures for the appeal of Enforcement orders. The questions to be addressed are whether Conservation Commission Enforcement Orders are appealable through the DEQE administrative process or only to a court: and who may appeal Enforcement Orders issued by the Department.

First: Conservation Commission Enforcement orders are not appealable to the Department. They can only be appealed to the superior Court.

Second: the Department's Enforcement Orders are appealable through the administrative process. But the individuals who have standing to raise such an appeal are different from those who may appeal the Department's Superseding orders.

The wetlands Protection Act Regulations, in 310 CMR 10.05(7)(j). provide that Superseding Orders and superseding Determinations may be appealed for an adjudicatory hearing by any person specified in $10.05(7)(a)$. Thus, each superseding order issued by the Department includes the standard appeal paragzaph. 

The regulations regarding the Department's Enforcement Orders set forth in 10.08, however, do not refer to 10.05(7)(a). Thus. appeals from the Department's Enforcement orders are not available to all of the potential appeliants listed in $10.05(7)(a)$. Only those individuals who fit the definition of a "party" found in the Department's Rules for Adjudicatory Proceedings. 310 CMR $1.01(2)(c)(5)$ may appeal one of the Department's Enforcement Orders..

The attached form contains appropriate wording for the Department's Enforcement order appeal paragraphs.

MW/mea

$1088 \mathrm{~A}$ 

- Completed application forms and plans as required by the Act and Regulatrons shall be filed with the on or belore (dale).

and no further work shall be performed unill a public hearing has been held and an Order ol Conditions has been issued to regulate said work. Applicalion forms are available at:

- The property owner shall take every reasonable step lo prevent futher violations of the act.

$\square$ Other (specify)

Failure 10 comply with this Order may conslitule grounds for legal action. Massachusetts General Lav's Chia. ler 131, Section 40 provises:

Whoever violates any provision of this section shali be punished by a line of not mo:e then one ihousand dollars or by' imiprisonment for not more than six months or boith. Each day or portion thereol of continuing violeion shali constitute a sepa:ate oiltense.

Questions rega: ding this Enforeement Oider should be direcled lo:

issued by

Signature(s)

(Signaiure of delivery person

or certified mail number)

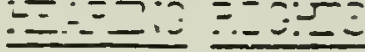

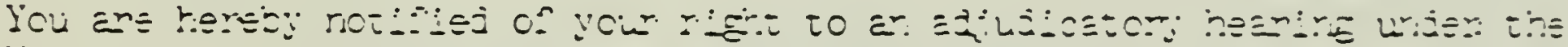

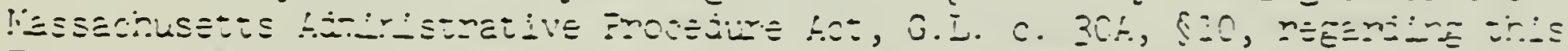

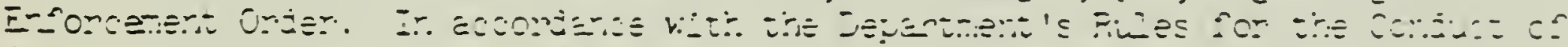
L m

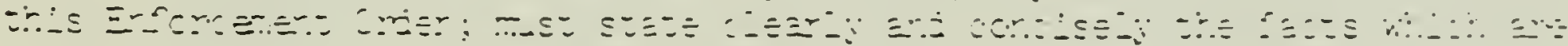

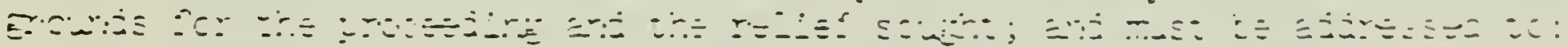

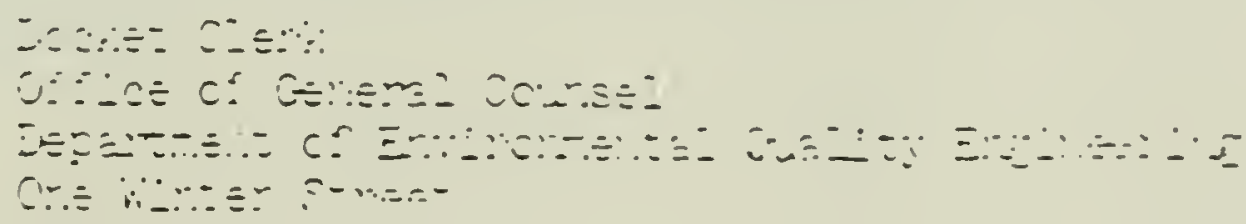





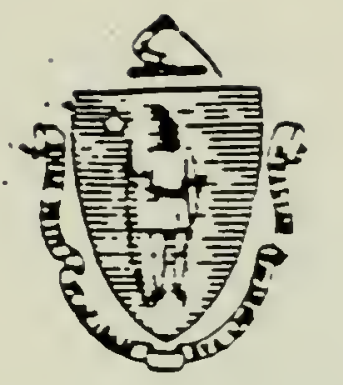

The Commanuealth of Massachusetts

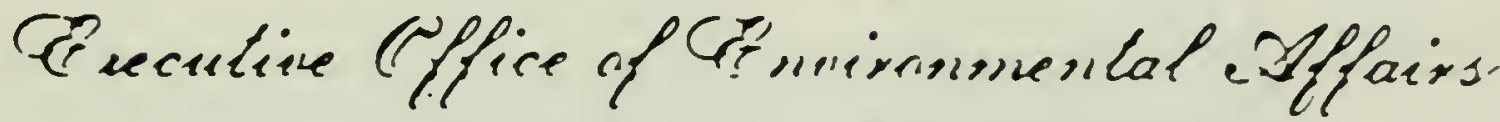

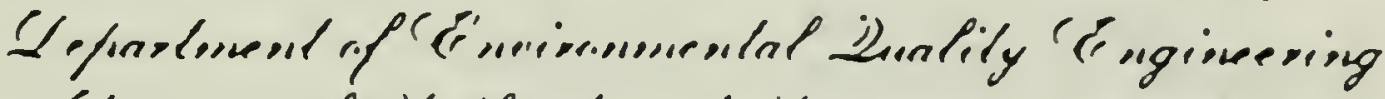

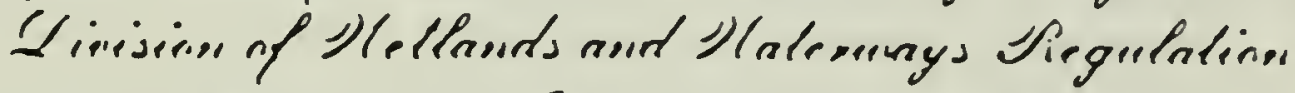

S. RUSSELL SYLVA

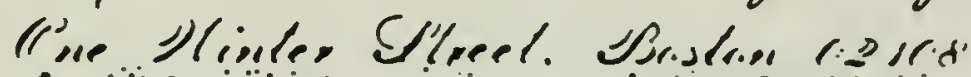

MEYORANDUM

IO:

Reglonal Environmental. Englneers

Wetlands Prorection Program Siaff

Legal office

FROM:

Meriel Hardin, Acting Diretopfy

DATE:

Septeaber 17,1985

SUBJECT:

Wetlands Protection Program Pollcy 85-4

Procedures for Amending an Order of Conditions

Following the issuance of an Order of Conditions, clrcumstances sometimes arise, such as subsurface conditions encountered upon comencement of construction or reculrements of other'stace or: loctl.permits -1ssued subsequent to the Order,. that may require modifications of the plans approved in that order. To allow for the smooth operation of the peroitting procedure and to avoic unnecessary and unproductive duplication of regulatory effort, the Departwent recognizes that it would not be reasonable to require a complete refiling of the Notice of Intent when the changes sought in the Order of Conditions are relatively =inor and wil have little or no impact on the interests protected by the Ac:. Thus, the process of anending an Order of Conditions is acceptable to the Departuert as lons as certain procedural safeguards are eaployed.

In processing an amendrent to an Order of Conditions, thi. Depertwent reconmens that the following procedures be used for all but the mosi siagie changes, such as correcting obvious mistakes or typographical errors:

1) The applicant should make a request for an amencment to the conservation comission either orally at a reqularly scheduled reeting c: the coutission or by sub-.itring the request to the co=ission in. witing. In either case, a written copy of the regues shouic also be forwarded to the Department's regional office.

2) The conservation comission first wakes a deterina:ion whethe: the requestec change is substantial enough to warrant the jiling cf a new Notice of Intent or whether it is of a relativeiy tinor nature anc can be considered as an amendment to the original order of Concisions. In raking this des:-inarion, the comission should consider such factors as whether the purpose of the project has changed suosianiall $\because$, whethe: the scope of the project has increased substantially and whe the the potential for adverse inpacss to the prorected siaturory incerests will be Increased substantially. 

3) If the comission detemines that a new Notice of Inten: is not necessary, the commission should publish newspaper notice (at the applicant's expense) in the same general manner as outined in the Act for new Notices of Intent and as required by the Open Yeeting Law, G.L. C. 39, S 23B, to Inform the public that the reques: for amendment to the Order of Conditions will be considered by the

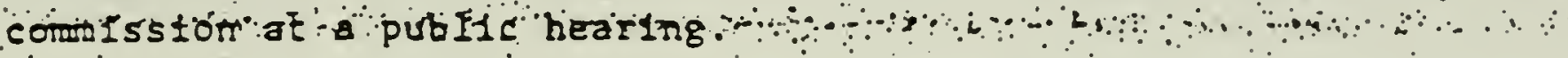

4) If, after considering the information presented by the appilcant and any comments received at the public hearing, the commission decides to 1ssue an amended order of conditions a copy of such order should be forwarded to the Department's regional office at the time of issuance. By analogy to the normal appeal procedure of the original Order of Conditions, a person aggrieved by the changes made to the amended order, or the other parties given appeal rights by the Act, may, within ten days of issuance., request that the Department review the changes made tc the origina? Order of Conditions. In that case, until there is a inal resolution of the appeal no work may continue on those por:icrs of the project not permitred under the original Order of Conditions but only permitted by the amendment(s) which has been appealed.

MII/mes 



\section{The Commonwealth of Massachusetts}

Exscutive Cffice of Envixanmental Affaix Depaxtment of Envixanmental Duality Engineexing S. RLSSELL SYLYA One Wintox freet, Boston 02108 Commissinner

\section{MEMORANDUM}

TO: Regional Environmental Engineers Wetland Program Staff

Legal Office

FROM: Roderick Gaskell, Director

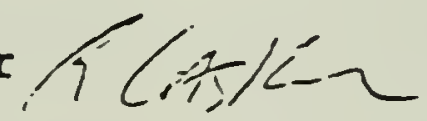

DATE: January 24, 1985

SUBJECT: WETLAND PROGRAM POLICY $85-2$

INTERPRETATION OF 310 CMR $10.57(2)(b)$

DEFINITION OF ISOLATED LAND SUBJECT TO FLOODING

"Land subject to flooding" has been divided in the regulations into two different types of areas, those which flood as a result of water rising from creeks. ponds. rivers. or lakes, and those which flood due to ponding of run-off or high ground water. See generally 310 CMR 10.57. The characteristics of these different types of areas are defined in $310 \mathrm{CMR}$ 10.57(2). The interests served by these areas are set forth in the discussion section and the performance standards. $\$ \$ 10.57(1)$ and $10.57(4)$ respectively.

One of the principal purposes of the explicit definition of isolated land subject to flooding ("ILSF") is to differentiate between those areas that serve these interests in a significant way and areas where small amounts of water may collect occasionally--puddles, in effect. A second purpose is to distinguish between those areas that are important parts of a larger water resource system--for which the cumulative effects of even small fillings can lead incrementally to serious flooding problems over the entire floodplain--and those that are only locally significant to the interests of storm damage and flood prevention. By making these distinctions, the regulations provide an appropriate degrees of protection to land areas that function in different ways. A third purpose is to ensure consistent application of the distinctions by regulators across the state, providing a greater degree of certainty for land owners with regard to the standards of review they should expect. 

Unfortunately, there has been some confusion as to the interpretation of the definition of an ILsF. reducing the degree to which consistent administration has been achieved. As in certain other areas of the regulations (see, e.g. Wetland Policy Memorandum 85-1). the selection of numerical criteria in an effort to provide specific guidance has raised subsidiary technical questions that were not critical when the standards for determining jurisdiction were less clearly defined. This memorandum will set forth. for the guidance of land owners. developers, and regulators, the Department's interpretation of specific portions of its regulations defining an ILSF.

(1) "An isolated depression or closed basin without an inlet or an outlet". The phrase "without an inlet or an outlet" is not intended as a literal exclusion of all sources of flow. chanelized or otherwise, into a basin. Obviously, any basin must have an "outlet" of some kind at some elevation. at which the basin would be overtopped: similarly. there must be some flow of water into the basin (whether through ground or surface water) if there is any accumulation. In the context of this definition. "inlet" is intended to refer only to a hydrologic connection with the 100-year flood event on a water-body: that 18. "Inlet" is only used to distinguish ILsF from a bordering land subject to flooding. which has such a hydrologic connection. A different set of performance standards. approprlate to the flood storage function within the larger system, applies to the bordering land subject to flooding. Thus, a basin which receives a channelized flow generated by run-off may constitute an ILSF, if the remaining elements of the definition are met. even though such a channel could be termed an "inlet" in some sense. Similarly. the existence of an "outlet" at a certain elevation does not preclude a finding that a basin constitures an ILSF, if the requisite volume of water is confined within the basin below that elevation.

(2) "An area which at least once a year confines standing water ...". "At least once a year" refers to a statistical event with a one-year return period. and is not dependent on direct annual observations and measurements of volumes confined within a specific basin. The observation that the requisite volume of water was or was not confined within a specific basin in a particular year is not conclusive. though of course in may be relevant. to a determination that the basin is or is not an ILSF. The methodology of the calculations should be consistent with that described in $\$ \$ 10.57(2)(b)(3)$ and (a)(3). except that the calculation should be based on a 24 -hour event with a one-year return period.

(3) Boundary of ILSF. The boundary of an ILSF is defined in $\$ 10.57(2)(b)(3)$ as the largest observed or recorded volume of water confined within the area. In the event of dispute. calculations regarding the extent of the $100-y e a r$ flood event. are used to determine the probable extent of such water. The lateral boundary of the ILSF is the area that will be inundated 

duElng that event. As 1ndlcated above, if there is an outlet at a glven elevation such that water will not be confined within the basin above that elevation. the outlet elevation should generally represent the boundary of the area (unless water will continue to be contained above that elevation despite the presence of an outlet). Thus, the boundary of the ILSF is elther the elevation at which retained waters reach an "outlet" and flow out of a ILSF basin, or the area of inundation resulting from a loo-year storm if there is no such outlet. The calculations should assume that the surface of the ILSF basin is impervious, but should use standard methodologies to account for infiltration within the contributing watershed based on the relative proportions of previous and impervious surfaces.

It is important to note that two sets of calculations may be relevant for determining the existence and extent of an ILSF. First, the l-year storm calculation is a threshhold determination of jurisdiction. If the calculations show that the requisite volume of water is confined within a particular basin, the basin is an ILSF. Second. in making a boundary determination for areas that meet or exceed the threshhold. the 100-year storm calculation or the location of an outlet may be used. In both cases. the calculations should assume no infiltration within the ILSF, basin itself, but may make standard assumptions with respect to infiltration within the contributing watershed. 

duElng that event. As Indicated above. if there is an outlet at a given elevation such that water will not be confined withln the basin above that elevation. the outlet elevation should generally represent the boundary of the area (unless water will continue to be contained above that elevation despice the presence of an outlet). Thus. the boundary of the ILSF is elther the elevation at which retained waters reach an "outlet" and flow our of a ILSF basin. or the area of inundarion resulting from a loo-year storm if there is no such outlet. The calculations should assume that the surface of the ILsF basin is impervious, but should use standard methodologies to account for infiltration within the contributing watershed based on the relative proportions of previous and impervious surfaces.

It is important to note that two sets of calculations may be relevant for determining the existence and extent of an ILSF. First, the l-year storm calculation is a threshhold determination of jurisdiction. If the calculations show that the requisite volume of water is confined within a particular basin. the basin is an ILSF. Second, in making a boundary determination for areas that meet or exceed the threshhold. the 100-year storm calculation or the location of an outlet may be used. In both cases, the calculations should assume no infiltration within the ILSF basin itself, but may make standard assumptions with respect to infiltration within the contributing watershed. 



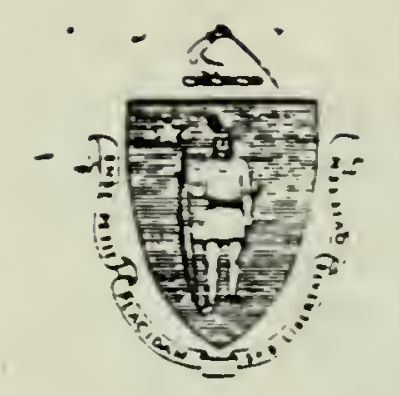

S. RL'SSELL SILY'A

Commissioner

\section{The Commonwealth of Massachusetts}

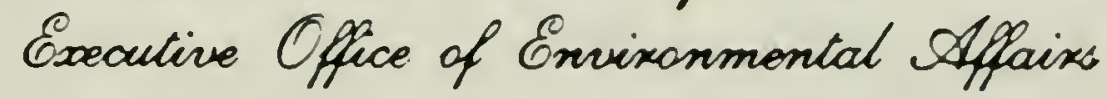
Deparement of Ëmixonmental Quality Ëngineering One Wintex firred, Bostan 02108

\section{MEMORANDUM}

To: Regional Environmental Engineers Wetland Program staff

Legal office

FROM: Roderick Gaskell. Director/

DATE: January 24. 1985

SUBJECT: WETLAND PROGRAM POLICY $85-1$

INTERPRETATION OF 310 CMR $10.55(2)$ (c)

VEGETATION "IDENTIFIED IN THE ACT"

The definition of Bordering vegetated wetlands is found at 310 CMR 10.55( 2$)$. In part, that definition provides that "[ $t]$ he boundary of Bordering vegetated wetlands is the line within which 50 percent or more of the vegetational community consists of the wetland plant species identified in the Act". The reference is to the plant species identified in numerous paragraphs of M.G.L. C. 131540 in which various types of bordering vegetated wetlands (e.g. bogs. swamps, wet meadows. marshes) are defined by vegetational communities. In each of the statutory definitions. a list of plant species and genuses is preceeded by a phrase that is essentially equivalent to the following: "a significant part of the vegetational community is made up of, but not limited to nor necessarily including all. of the following plants or groups of plants."

Difficulty in intrerpreting this language has been compounded by the fact that the lists of plants and groups of plants are not exhaustive. The lists omit some species that are generally recognized as excellent wetlands indicators. that is. plants that grow exclusively (or nearly so) in wetlands. The lists also include some species that are poorer indicators than some of the species omitted. Prior to the adoption of $\$ 10.55$. this issue was not crucial because the regulations did not contain a numerical interpretation of the phrase." "a significant part of the vegetational community". In locations where indicator species that were not listed by name were present, species that were specifically listed were also likely to be present, and jurisdiction over the area was ofien

established. 

Because $\$ 10.55(2)(c)$ establishes a numerical limitation. it has become essential to interpret the statutory language defining wetlands areas. The Department therefore interprets the statutory phrase "not limited to" as incorporating plant species or groups similar to those listed by name. insofar as such non-listed species or groups are at least as likely as those specifically named to indicate wetlands. Such plants serve essentially the same wetland functions as those listed by name, and thereby serve the interests of the Act in essentially the same manner. The Department believes that the legislature did not intend to limit the definition of wetlands to the technical knowledge then available. that the legislature intended that plants exhibiting similar characteristics to those identified should be considered. and that the legislature employed the words "not limited to ... the following plants or groups of plants" to indicate this intention. Accordingly. plants generally accepted as indicative of wetlands, and identified as such in generally accepted scientific or technical publications. may be considered to be wetland plant species "identified in the Act" in determining the boundary of bordering vegetated wetlands.

It is important to recognize that the hydrologic and topographical elements of the definition of bordering vegetated wetlands, set forth in the Act and in $\$ 10.55(2)(a)$ and (b). must still be satisfied. These requirements are unaffected by this interpretation.

Document $0048 \mathrm{~W}$ 



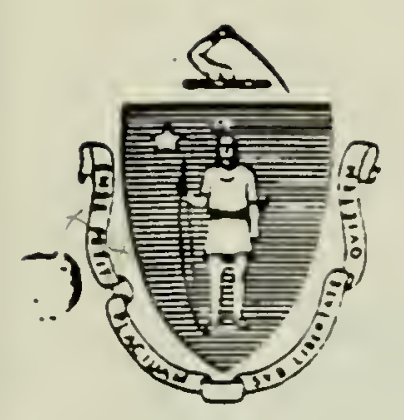

Massachusetts Dept. of Environmental

Quality Engineering

Division of Wetlands and Waterways Regulation One Winter Street

Boston, MA 02108

(617) 292-5695
Massachusetts Dept. of the Attorney General

Environmental Protection Division One Ashburton Place

Boston, MA 02108

(617) 727-2265

In 1972 the Wetlands Protection Act ("the Act") was amended to give the conservation commission the initial responsibility for the administration of the statute. In addition to issuing regulatory Deteminations of Applicability, Orders of Conditions, Extensions and Certificates of Compliance, a conservation comission is in an excellent position to take enforcement actions. We recomend the following enforcement procedures to help conservation comissions obtain compliance with the Act.

\section{Step1. Determination of a violation and site inspection}

Failure to comply with a Determination of Applicability or an Order of Conditions and work in areas subject to the Act without a valid Order of Conditions constitute violations of the Act. Violations can include, among others, the failure - to file a Notice of Intent, to observe a particular condition or time period specified in a Determination or Order, to record an Order in the Registry of Deeds or to obtain an Extension Permit. The DEQE and conservation comissions are equally authorized and responsible for enforcing the Wetlands Protection Act. This means that:

A. A conservation comission, at its discretion, can enforce a DEQE Order. The DEQE regional office should be notified as quickly as possible of any violations of Superseding Orders. If DEQE supports enforcement actions by the conservation comission, but is unable to respond quickly enough or at all, the comission should proceed promptly with its own enforcement action.

B. The DEQE, at its discretion, can enforce a conservation comission Order. The State may take enforcement action if the person requesting such action has reasonably documented improper or no action by the commission, or if requested to act by the comission for good cause. $D E Q E$ encourages comissions to enforce their own Orders.

C. Both DEQE and the conservation comission can pursue a violation where work is being done in an area subject to the Act without a valid Order.

Commissioners or their agents, upon learning of a violation, should promptl: visit the site, take pictures and record relevant data such as iocation, the names of equipment operators, pertinent license plate numbers, the estlmated type and amount of fill, water levels, etc. Photographs should show the extent and type of violation and have the time, date and location legibly witten on the back alons with the photographer's name, address and phone number. 
Conservation commission members, their agents, officers and employees have the right to enter upon open fields, woods and wetlands without a warrant to carry out their statutory responsibilites; however, it is good pollcy to contact the property owner or the person in charge of work at the site before entering onto the land to give notice of the site inspection. Because some property owners are not aware of this inspection authority, comission members may find it appropriate on occasion to be accompanied by a police officer when inspecting a site.

\section{Step 2. Request for Compliance and Enforcement Order}

Depending on the extent and serlousness of the violation, the conservation commission may decide to proceed with varying degrees of formality.

A. Request for Compliance

If the violator is simply unaware of the law and will comply once notified, an informal verbal request for compliance might be made before 1ssuing an Enforcement Order.. Or, if no activity is taking place at the moment, but. 1llegal activitles have taken place, a a letter requesting compliance may be sultable. If no response is made, an Enforcement Order should then be sent. It is essential to document each action taken.

B. Enforcement Order

If no response is made to the request for compllance or if work is taking place and there is an 1mediate need to stop the activity, the conservation comission should issue an Enforcement Order. See Form 9 In the Wetlands Regulations ( 310 CMR 10.99). An Enforcement Order constitutes a formal notice of violation and must be slgned by a majorlty of the comission. In a situation requiring imediate action, an Enforcement Order may be signed by a single member or agent of the comission if the Order is ratified by a majority of the members at the next scheduled meeting of the commission. The Enforcement Order should be delivered by a rellable method such as certified mail (return receipt requested) or hand delivery. Police officers are somerlmes used to deliver them.

\section{Step 3. Court action by local authority}

If a violator ignores the Comission's Enforcement Order, the conservation comission should seek judicial enforcement.

A. Civil Action

Ask Town Counsel or the City Solicitor to flle a Complaint in Superior Court on behalf of the municipality against the violator of the Act. When the comission belleves that Tow Counsel or the C1ty Solicitor is not enthusiastic about enforcing the Act, the request should be made in writing setting forth the reasons court action is warranted and a date by winch you would like the complalnt filed. A realistic time 

span within which the town's or c1ty's attorney should file the Complaint is 10 days to 2 weeks. In cases where continuation of the activity will cause irreversible harm, ask Town Counsel to f1le a Complaint imediately.

In situations involving valuable wetland resources where serlous, irreversible alterations are occurring, Counsel should be asked to seek a Temporary Restraining Order. A T.R.O. can be issued 1medlately, whout notice to the violator. It remains in effect no more than 10 days, however, and the parties must appear in court to have a T.R.O. extended to a Preliminary Infunction, which continues unt1l trial.

A Complaint which remains unresolved leads to a trial. Since a full trlal could be delayed in many counties because of crowded court dockets, counsel should be asked to seek a Prellminary Injunction from the Court which orders an imedlate halt of all 1 llegal wetlands alterations on the subject property. Obtaining a Prel1minary Injunction can involve several days because the defendant must be given notice and an opportunity to appear in court.

Both a Prelfminary Injunction and a Temporary Restraining Order can be requested only in conjunction with the filing of a Complaint. Model Complaints are available from the Attorney General's office if needed by Town Counsel or C1ty Sollcitor.

To file a Complaint. Counsel for the municlpality will have to be able to demonstrate that a violation has occurred. Therefore, the comission should provide him/her with the following:

1. Photographs;

2. Statement(s) from comission members or others who have observed the violation, incorporating the labeled photographs and authenticating them as a "falr and accurate representation" of the property as they saw it; and

3. Coples of the Enforcement Order and any other relevant correspondence.

B. Criminal Action

While a civil action is more approprlate for achieving remedial results such as the restoration of a site, criminal action is betrer sulted for achleving punitive results (flnes or 1mprisonments). In cases of flagrant violations, comissions may wish to proceed in criminal court. A sympathetic District Court can be helpful to the wetlands protection efforts of a conservation commission.

A criminal action may be inftiated by any person, including the conservation commssion. The action is 1nitlated by submiting to the clerk of Court a statement of the violation which specifies the: 

1. type and extent of the violation;

2. name and address of the violator:

3. location of violation:

4. date of violation; and

5. Statute which has been violated (G.L. ch. 131, \$ 40).

Indfate that this statement has been approved by vote of the conservation comission and include names and addresses of witnesses to the violation plus clearly 1dentified photographs. Also include the Enforcement Order and any other relevant documentation.

\section{Step 4. State assistance in enforcement}

If Town Counsel or the City Solicitor fails to respond to the written request of a conservation comission for legal enforcement action, or if the conservation comission is unsuccessful in enforcing a State Superseding Determination or Order, the commission can seek help from the State. A letter requesting support in an enforcement action should be sent to the DEQE Regional Environmental Engineer with a copy to the Environmental Protection Division of the Department of the Attorney General. Complete documentation including copies of the Enforcement Order and correspondence with counsel should be enclosed. When requesting this assistance,

7 it is important that the commission demonstrate that it has made every effort

- to deal with the probler at the local level.

There are a number of factors that the State wlll take into consideration in deciding whether or not to pursue enforcement action, including the seriousness of the violation, the degree of environmental harm, the likelihood of preventing future violations, the availability of enforcement resources and the probability of achieving a successful result. If DEOE determines l1tigation is necessar:, the case will be referred to the Attorney General's Office. Such referral means that, should no settlement be reached, conservation commission members and oriner local officials are prepared to do the work required to go to court.

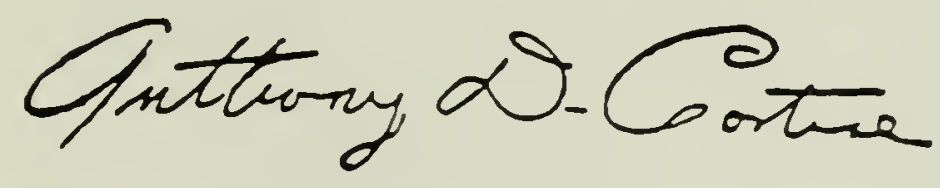

ANTHONY D. CORTESE, SC.D. Commissioner

Department of Environmental

Qualizy Engineering

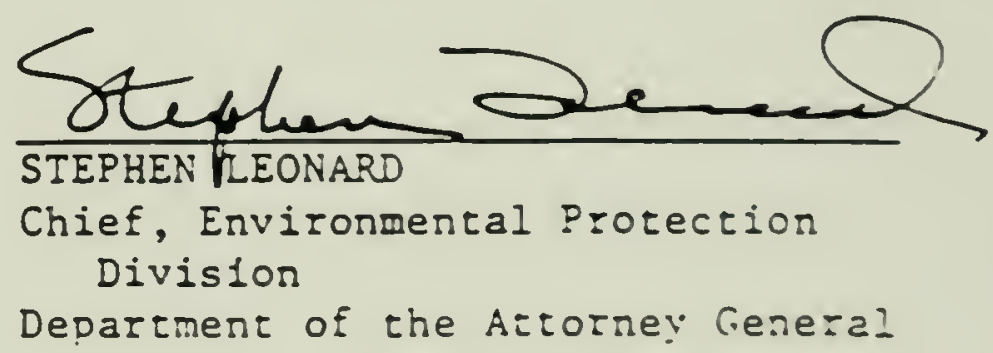





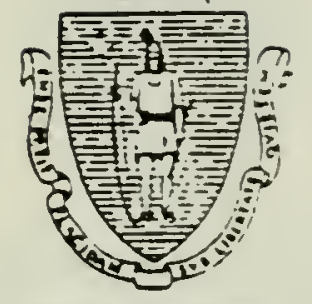

ANTHONYD. CORTESE, SC D.

Commissloner

The Commonwealth of Massachusetts Execulive Office of Ensixanmental Affaixs

Depaxtment of Envixonmental Duality Engineexing

Division of Wettands Pratection

one Wintex fixeet, Boston 02108

(617) 292-5519

MEMORANDUM

TO: Northeastern and Southeastern Regional Engineers and Coastal Wetlands Stafi

FROM: $\quad$ Roderick Gaskell, Director

Division of Wetlands Protectioñ

DATE: $\quad$ February 24,1982

SUBJECT: Variance and Salt Marsh Policies, Coastal Wetlands Regulations (Policy No. 82-1 and $82-2$ )

Attached for your information and for filing in your policy notebooks are two new policies which further clarify the Coastal Wetlands Regulations. Policy no. 82-1 sets forth the standards for issuance of a, variance Policy no. 82-2 makes it clear that section $32(5)$ of the Coastal Wetlands Regulations, which provides for the restoration or rehabilitation of salt marsh, does not permit the destruction of salt marsh even if compensatory measures are proposed.

RG : cam

CC: D. Fierra, Deputy Commissioner C $2:$ 


would be applied in future cases. Although no one but the Commissioner is empowered to Erant a vaniance under section 36 , it is important that the Wetlands Staff be aware of the applicabie standards since they will have to advise the Commissioner on future variance requests as well as respond to incliiries by applicants, Conservation Commissions, and the general pliblic. Thus, what follows is an explanation of each of the variance criteria which the Department will consider in evaluating a reguest for a variance.

For the first requirement - the provision of protection equal to that provided by the regulations - the resource area 1mpacted must be identified, along with the interests of the Act protected by that resource area. Then, the applicant for the variance must demonstrate that the alternative applicable means of protection will protect the interests of the Act to the same degree as the coastal regulations, and the alternative must be real, specific, permanent and enforceable.

Whether the second requirement - the service of an overricins olblic interest - has been satisfiec requires a findine that the project be constructed by or under the auspices of a public authority or a private entity found to be serving a public function. In aditior, for the project to satisfy the overriding public interest requirement, the public interest project must be one of unusual merit in order to override the applicable coastal regulatior.

As for the third requirement - the necessity for the variance there must be a showing that the nature of the project is such that it cannot be constructed so as to accomodate the ovenniding pubijc interest unless a variance is granted. In making tris showing, consideration should be given to alternative project locations anc designs, including divisable segments, size, and site plans. The inquiny into alternatives need not be limited to modifications of the project as orifinally proposed by the applicant, but shall explore other reasonaile options and alternatives which could avoid non-compliance with the applicabie coastal regulation, including alternative means of sezisfyins the overniding public interest unrelated to the orifinal propos

As stated in the commentary to section 36, the vaniance provision. is intended to be employed only in rare and unuslial cases, and the applicant requesting the variance has the burden of satisfying eaci? element of the three requirements. licreover, the mere satisfactic: of these minimum requirements does not mandate the granting of a variance, for Section 36 provides that tre Commissioner may waive the application of any regulation in Part II. Conseouentiy, the uItimet variance decision is subject to the descretion of the Commissioner, even if the findings required by section 36 are resolved in favor of the applicant requesting the variance. In exercising his discretion, the Commissioner will considen apolicabie administrative anc executive orders, including the poliaies embodied in the Massachlis? Coastal Zone ilanagement Program. 



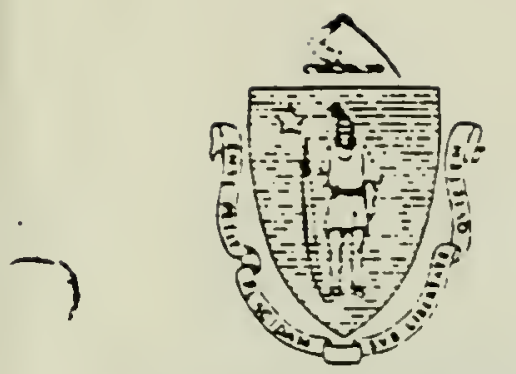

ANTHONY D. CORTESE, SC. D.

Commissioner
The Commonuealtr of Massachusetts orseculive Office of Envixmmental Affaix Depaxtment of Envixanmental Quality Engineexing Division of Hethand Protection one Wintex fireet, Baston 02108

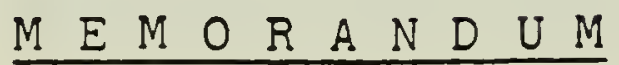

TO:

Regional Environmental Engineers

Wetland Program Staff

Legal Office

FROM: $\quad$ Roderick Gaskell, Director

DAFE: $\quad$ February 16, 1982

SUBJECT: WETLAND PROGRAN POLICY $82-2$

APPIICABILITY OF SECTION $32(5)$

OF THE COASTAL WETLANDS

REGUIATIONS, 310 CMR $10.32(5)$.

The general performance standard applicable to projects affecting a sait marsh is Section $32(3)$ of the Regulations for Coastal Wetlands, 310 Cif $10.32(3)$, which states, in Fan:

A proposed project in a salt marsh, on lands within 100 feet of a salt marsh, or in a body of water adjacent to a salt mansh shall not destroy any portion of the salt marsin and shall not have an adverse effect on the productivity of the salt marsh.

Section 32 (5) of the resulations, 310 CMR 10.32 (5), modifies tinat regulation and provides:

Notwithstanding the provisions of Section

$32(3)$, a project which will restore on rehabilitate a salt marsh, or create a sali marsi, may ie permitied.

This latter section is applicabie orly to projecss, the pri... purpose of which is the restoration, renabilitation or creatio:: of a salt marsh, but the accomplisinment of which may involve minon or temporany aciverse effects on poritions of the existins.mansh. It does not permit the cestruction of a salt marsh incicental to construction in coastal aneas even if compensaiony measunes ane

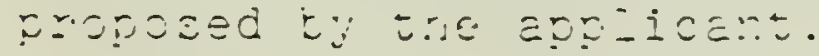



Thus, for coastal projects which are proposed for purposes other than salt marsh restoration, rehabilitation or creation, and which would destroy a salt marsh, or a pontion thereof, Section 32(3) would apply even if measures, slich as relocation of the salt marsh or creation of a new salt marsh, were proposed in an attempt to compensate for the destruction of the marsh. Section $32(3)$ requires the issuance of an Order of Conditions prohibiting the destruction of a salt marsh in these situations; although under section 36, the applicant may request a variance from the Commissioner if the project meets the applicable standards. 



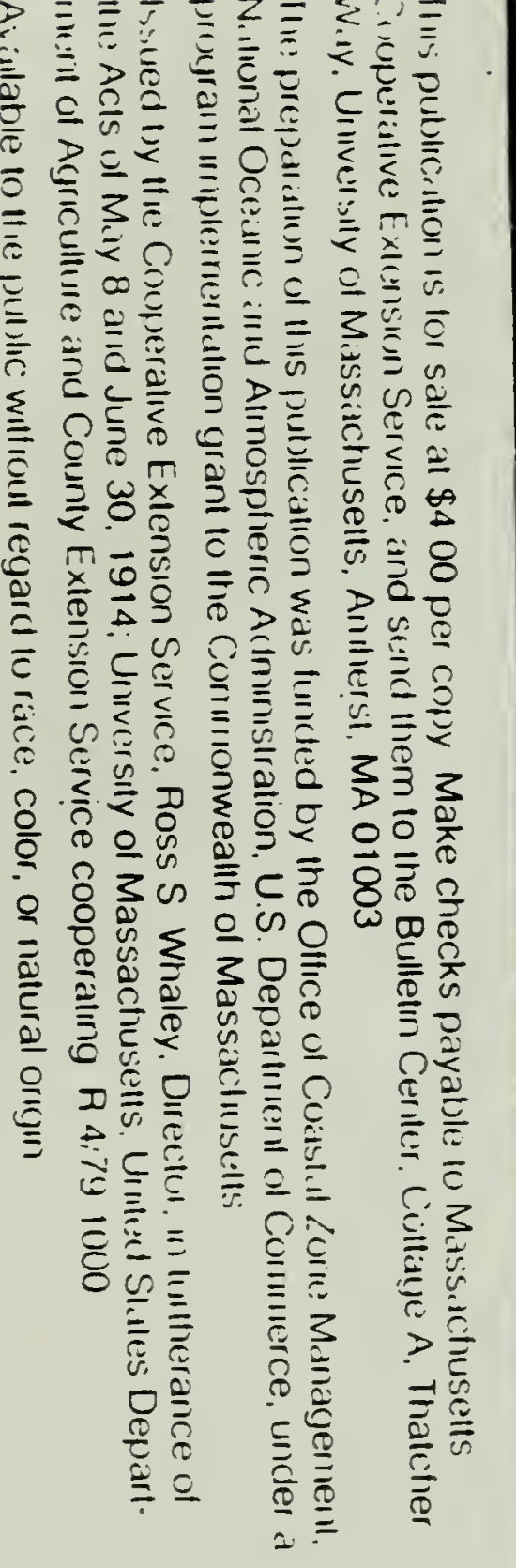

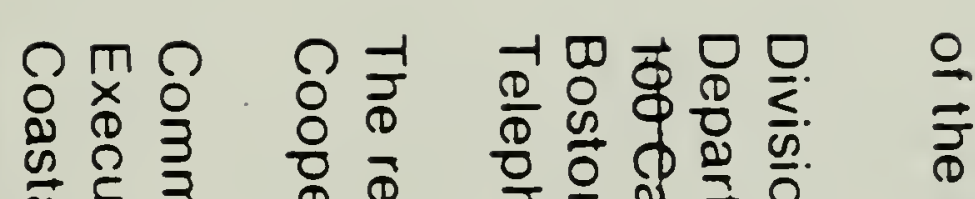

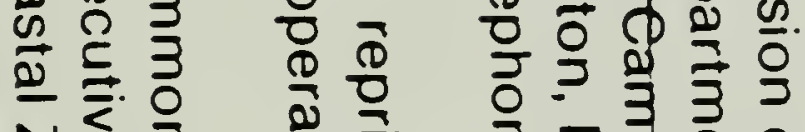

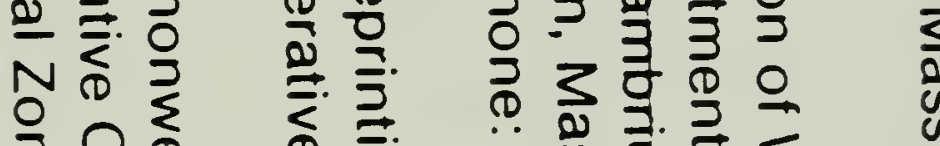

ते

उते

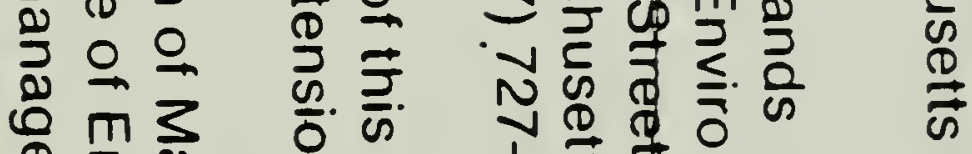

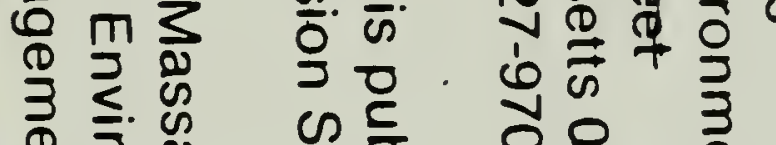

ఏำ

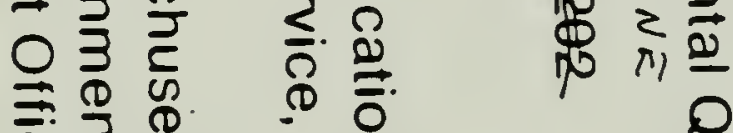

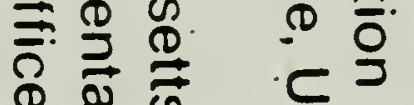

กิ $\stackrel{\vec{D}}{\overrightarrow{\mathrm{H}}} \sqsubseteq 5$

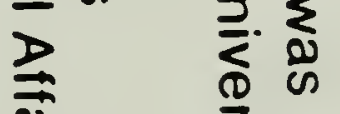

ज.

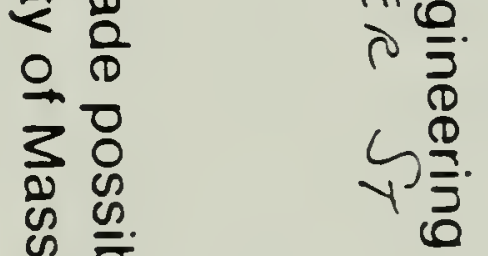

$\therefore \sum \frac{\mathscr{C}}{2}$

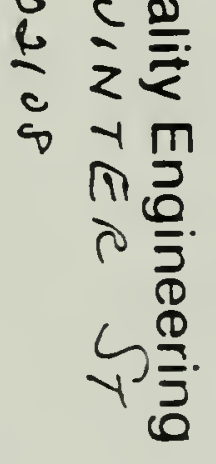

100

1000

ए 2 a

$\frac{\sum_{0}^{0}}{\stackrel{0}{0}}$

ํำ

$\rightarrow$

20

(1)

0

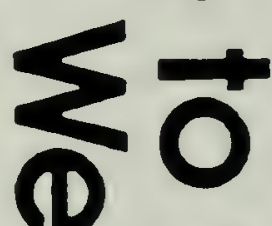

40

28

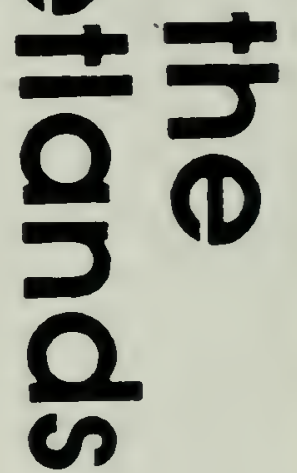

ปิ $\frac{\sigma}{0}$

₹

$\stackrel{Q}{\overrightarrow{0}} \overrightarrow{0}$

$\stackrel{\text { อ }}{\stackrel{0}{3}}$

$\stackrel{3}{3}$

$\vec{\omega}$

n

Dㅇ 


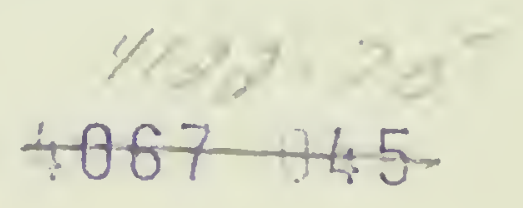



